\title{
Örgütsel Sinizm Algılanan Örgütsel Sinerjiyi Nasıl Yordar? Eğitim Örgütlerinde Bir İnceleme
}

\author{
Tuba AKPOLAT ${ }^{1}$ ve Ebru OĞUZ ${ }^{2}$
}

$\ddot{O} z$

Bu çalışmanın amacı öğretmenlerin örgütsel sinizm düzeyinin algıladıkları örgütsel sinerjiye etkisinin incelenmesidir. $\mathrm{Bu}$ amaçla, çalışma genel tarama modellerinden ilişkisel tarama modelinde tasarlanmıştır. Çalışmanın örneklemi olasılıklı örnekleme yöntemlerinden biri olan basit tesadüfi örnekleme ile belirlenmiştir. Örneklem 2019-2020 eğitim öğretim yılında İstanbul İli Avcılar İlçesinde görev yapmakta olan 396 öğretmenden oluşmaktadır. Araştırmanın verileri Örgütsel Sinizm Ölçeği ve Örgütsel Sinerji Ölçeği ile toplanmıştır. Veriler JAMOVİ istatistik programında parametrik teknikler kullanılarak analiz edilmiştir. Araştırmanın sonucunda öğretmenlerin örgütsel sinizm tutumunun düşük düzeyde ve örgütsel sinerji algısının orta düzeyde olduğu görülmüştür. Öğretmenlerin branşlarına, kıdemlerine ve yaşlarına göre örgütsel sinizm tutumlarında ve örgütsel sinerji algılarında anlamlı farklılıklar olduğu sonucuna ulaşılmıştır. Ayrıca öğretmenlerin örgütsel sinizm tutumunun algıladıkları örgütsel sinerjiyi ters yönde anlamlı bir şekilde yordadığ1 görülmüştür.

Anabtar Kelimeler: Örgütsel Sinizm, Örgütsel Sinerji, Öğretmen

How Does Organizational Cynicism Predict Perceived Organizational Synergy? A Study in Educational Settings

\begin{abstract}
The aim of this study is to examine the effect of teachers' level of organizational cynicism on their perceived organizational synergy. For this purpose, the study was designed in relational survey model which is one of the quantitative designs. The sample of the study was determined by simple random sampling, which is one of the probabilistic sampling methods. The sample consists of 396 teachers working in Istanbul Province Eyüp District in the 2019-2020 academic year. The research data were collected by the Organizational Cynicism Scale and the Organizational Synergy Scale. The data were analyzed using the parametric techniques in the JAMOVI statistical program. As a result of the study, it was seen that teachers' organizational cynicism attitude was low and organizational synergy perception was at a medium level. It has been concluded that there are significant differences in the organizational cynicism attitudes and organizational synergy perceptions of teachers according to their branches, seniority and age. In addition, it was observed that teachers' organizational cynicism attitude had a significant negative predict on their perceived organizational synergy.
\end{abstract}

Key Words: Organizational Cynicism, Organizational Synergy, Teacher

\author{
Atıf İçin / Please Cite As: \\ Akpolat, T., Oğuz, E. (2021). Örgütsel Sinizm Alg1lanan Örgütsel Sinerjiyi Nasıl Yordar? Eğitim Örgütlerinde Bir \\ İnceleme. Manas Sosyal Araştırmalar Dergisi, 10(3), 1692-1705.
}

Geliş Tarihi / Received Date: 12.04.2021

Kabul Tarihi / Accepted Date: 06.05.2021

\footnotetext{
${ }^{1}$ Dr. Öğrt. Üyesi - Mimar Sinan Güzel Sanatlar Üniversitesi Fen Edebiyat Fakültesi, tuba.sagir.akpolat@msgsu.edu.tr D ORCID: 0000-0001-5907-6972

2 Prof. Dr. - Mimar Sinan Güzel Sanatlar Üniversitesi Fen Edebiyat Fakültesi, ebru.oguz@msgsu.edu.tr

(iD) ORCID: 0000-0002-5731-011X
} 


\section{Giriş}

Çalışanların örgütlerinde yaşadıkları deneyimler olumlu ve olumsuz birçok inanç ve davranışı içeren çok geniş bir yelpazeyi kapsamaktadır. Çalışan tutumları örgütlerin verimliliği ve etkililiği açısından büyük önem taşımaktadır. Bu bağlamda çalışanların olumsuz tutumlarının hangi algılara ne derece neden olduğunu bilmek önem taşımaktadır.

Örgütsel sinizm genel olarak kişinin istihdam edildiği örgüte (prosedürlerine, süreçlerine, yönetimine) karşı olumsuz bir tutumu ifade etmektedir. Üstelik bu olumsuz tutum genellikle örgütteki bu unsurların (prosedür, süreç, yönetim) çalışanın çıkarına aykırı çalıştığına dair bir inanca dayanmaktadır (Wilkerson, 2002, s. 553). Dean, Brandes ve Dharwadkar (1998, s. 345) örgütsel sinizmi, tutumu yansitan inançlara, duygulanıma ve davranışsal niyetlere odaklanarak tamamen tutumsal terimlerle tanımlamıştır. Örgütsel sinizmin bu üç boyutundan inançlar, çalışanların örgütsel uygulamaların adalet, dürüstlük ve samimiyetten yoksun olduğuna, kişisel çıkarların ön planda olduğuna, insanların güvenilmez olduğuna ve davranışlarının altında gizli ajandaların işlediğine dair inanışlarını içermektedir. Duygulanımlar boyutu, çalışanların örgütleri hakkında hissettikleri sıkıntı, tiksinti, utanç gibi güçlü duygu durumlarını ifade etmektedir. Davranışlar boyutu ise olumsuz ve aşağılayıcı davranışları içermektedir. Örgütsel sinizmin en belirgin davranış türünün alaycillk olduğu söylenmektedir. Örgütsel sinizm bir deneyim sonucu öğrenilmiş bir inanc1 temsil etmektedir (Andersson, 1996, s. 1397). Örgütün verdiği sözleri yerine getirmediğini hisseden çalşanlar, daha sinik davranışlara sahiptir (Johnson ve O'Leary-Kelly, 2003, s. 641). Bununla birlikte Wanous, Reichers ve Austin (1994, s. 269) yanlış yönetilen değişim çabalarına tekrar tekrar maruz kalmanın sonucunda örgütsel sinizm tutumunun ortaya çıktığını belirtmektedir.

Çalışanların geçmiş deneyimleri örgütlerinde sinik davranışlar sergilemelerine neden olabilir. Fakat bu davranışları çevresel değişkenlerin etkilerine bağlı olarak değişebilir (James, 2005, s. 70). Örgütsel sinizme neden olan ve örgütsel sinizmin neden olduğu örgütsel davranışlar incelendiğinde genellikle tükenmişlik (Simbula ve Guglielmi, 2010, s. 309), işten ayrilma niyeti (Güngör, 2019, s. 69), işe yabancilaşma (Akpolat ve Oğuz, 2015, s. 965), siyasi ayrımcilık (Keskinkilıç Kara ve Oğuz, 2016, s. 62) gibi olumsuz örgütsel davranışları artırdığı ya da bağlılık (Mahmood ve Sak, 2019, s. 2253; Okçu, Şahin ve Şahin, 2015, s. 305), örgütsel vatandaşlık (Andersson ve Bateman, 1997, s. 463), iş doyumu (Kahya, 2013, s. 42), örgütsel adalet (Bölükbaşıoğlu, 2015, s. 78; James, 2005, s. 70), güven (Akın, 2015, s. 183), motivasyon (Mert ve Yılmaz, 2019, s. 636) gibi olumlu örgütsel davranışları azalttığ1 görülmektedir. Alanyazındaki tüm bu sonuçlar örgütsel sinizm ile olumlu örgütsel davranışlar arasında ters yönlü bir ilişkiyi işaret etmektedir.

Sinerji kelimesi, "birlikte çalşmak" anlamına gelen Yunanca sinergos kelimesinden türemiştir. Örgütsel sinerji, iki veya daha fazla birimin veya örgütün, ayrı çalş̧abileceklerinden daha fazla birlikte çalışarak daha fazla değer üretme yeteneğini ifade eder (Goold ve Campbell, 1998, s. 133). Örgütsel sinerji, bireylerin birleşik bir güç oluşturmak için örgüt birimleri arasında birbirleriyle fikir ve bilgi alışverişi yoluyla iş birliği yaptıkları uyumlu ortamı yaratmak ve örgütün istenen hedeflerine ulaşmak olarak tanımlanır (Al Shaar, Khattab ve Alkaied, 2015, s. 501). Bu iki tanıma bakıldığında örgütsel sinerjinin, örgütün örgütsel faaliyetini destekleme kabiliyetini ifade ettiği söylenebilir (Jadesadalug ve Ussahawanitchakit, 2008, s. 119). Harris (2004, s. 359) sinerji ortaya çıkarma sürecinin dinamik olduğunu, uyum sağlamayı ve öğrenmeyi içerdiğini, bağımsız olarak hareket ederken birçok kişinin ortak eylemini içerdiğini, bütüncül bir çözüm yaratıldığını, takım üyelerinin potansiyelini geliştirildiğini belirtmektedir.

Örgütsel sinerji küreselleşme ve dijitalleşmenin iş dünyasına etkisi ile birlikte farklı işler yapan örgütlerin, kendi işlerinde yaratıcllık, yeni ürün geliştirme ya da örgüt içindeki herhangi bir süreci kolaylaştırma gibi örgütsel faaliyetleri gerçekleştirmek için yaptıkları ortaklığı ifade etmek için kullanılan bir kavram olarak alanyazına girmiştir. Bununla birlikte örgütsel sinerji tanımı gereği örgütsel başarı için örgütün iç unsurlarının birlikte işe koşulduğu bir süreci de ifade etmektedir. Sinerji kavramı, süreçleri etkili bir şekilde geliştirmek için kullanılan bir yaklaşım olarak toplumdaki, iş dünyasındaki ve eğitimdeki gruplar için geniş çapta tartışılmaktadır. Örneğin Covey (2002, s. 278) sinerjiyi yedi temel alışkanlıktan biri olarak tanımlar. Senge (2002, s. 216) takım öğrenmesini başarılı grupların anahtar disiplinlerinden biri olarak tartışı; sinerji, takım öğrenmesinin kritik bir parçası olarak belirtilir. Sinerjinin başarıyla üretildiği yaşam alanlarında, etkinliği artıran güçlü bir araç olduğu kanıtlanmıştır (Lick, 1999, s. 34). Sinerji, iş birlikçi veya birleşik eylemdir. Farklı bireyler veya insan grupları ortak bir amaç için iş birliği yaptığında ortaya çıar. Amaç, alg1 ve deneyimleri, iç görüleri ve bilgileri paylaşarak etkinliği artırmaktır (Harris, 2004, s.364). Conner (1993, s. 51) sinerij yaratma sürecinin dört aşamadan oluştuğunu belirtmektedir. Bunlar etkileşim, 
takdir edici anlayış, bütünleşme ve uygulama aşamalarıdır. Akpolat ve Levent (2018, s. 738) eğitim örgütlerinde değişimlerin neden olduğu çatışmaların hem örgütsel hem de kişisel olarak olumlu çözüldüğü durumlarda ortaya çıkan sinerjiye ilişkin gözlemlerinin ve Conner'ın (1993, s. 51) ortaya koyduğu sinerji yaratma süreçlerini temel alarak örgütsel sinerjiyi dört boyut altında incelemişlerdir. Bu boyutlar sırasıyla etkileşim ve takdir etme, strateji, bütünleşme, güncellenme ve güçlenmedir. Etkileşim ve takdir etme, örgüt içi iletişim unsurlarını içeren örgütsel sinerji boyutudur. Strateji bir işin başlangıç ve sürecinin kontrolünü kolaylaştıran, "ne zaman? nasıl? ve kim tarafından?" sorularının cevabının nasıl algılandığı ile ilgili örgütsel sinerji boyutudur. Bütünleşme, yaratıcılık, geçmiş deneyimlerden potansiyel çözümler ortaya koyma, esneklik gibi unsurları içeren örgütsel sinerji boyutudur. Güncellenme ve güçlenme ise kişisel olarak bilgi edinme ve edinilen bilginin paylaşılmasını içeren örgütsel sinerji boyutudur. Bir örgütte ne kadar fazla iletişim olursa bilgi sinerjisi o kadar artacaktır (Li, Chen ve Huang, 2006, s. 218). Dolayısıyla oluşan bu sinerji örgütün güncellenmesini ve güçlenmesini sağlayacaktır.

Örgütsel sinerji hem içsel hem de dışsal motivasyon türlerinin birlikteliğini gerektirir. Yüksek düzeyde kişisel ilgi ve katılım gibi içsel motivasyon unsurlarının maaş ve yetkinliği onaylayan ödüller gibi dışsal motivasyon unsurlarıyla birleştirilmesiyle ortaya çıkar (Amabile, 1997, s. 25). Bununla birlikte örgütsel sinerjinin ortaya çıabilmesi örgütsel bazı unsurları da gerektirmektedir. Harris (2004, s. 363) düşük sinerjili bir işin bireysel olduğunu ve çalışanlara yetki verilmediği bir örgüt kültürüne sahip olduğunu belirtmektedir. Bireyselliğin iş birliği, ortaklık ya da anlaşmalara mesafeli durulmasına neden olduğunu, değişime uyum sağlama konusunda direnmeye neden olduğunu belirtmektedir. Bununla birlikte genellikle sistemler ve politikaların paydaşlardan daha önemli olduğu düşünüldüğünden yöneticinin "kendi yöntemlerini”" dayattığını ve bu nedenle çalışanlara yetki verilmediğini ifade etmektedir.

Örgütlerin beşerî ve fiziksel iç kaynaklarını etkin bir şekilde kullanarak en yüksek faydayı sağlayacak sonuçlar üretmesi eğitim örgütleri açısından da elzem bir meseledir. Eğitim örgütlerinde sinerji ortaya çıarmak, örgütün verimliliği ve etkililiği için hayati düzeyde önemli olsa da kolay bir iş değildir. Öncelikle örgütte, sinerji ortaya çıarılabilecek örgüt kültürünün ve olumlu bir iklimin olması gerekmektedir. Bununla birlikte sinerjik bir eğitim örgütünün ön koşulları arasında gönüllülük, ortak hedeflere sahip olma, etkileşim, iş birliği ile katılım ve katkı sağlanmasına olanak tanıyan bir ortamın olması gerekmektedir (Lick, 1999, s. 38). Covey (2002, s. 279) sinerjiyi, eşlerin ortak hedeflere ulaşmak için paylaşımda ve yardımda bulundukları, samimi ve açık bir şekilde iş birliği yaptıkları sağlıklı bir evlilik örneği üzerinden açıklamaktadır. Dolayısıyla bir örgütte örgütsel sinerjiyi açığa çıkarmak için iki yönlü bir çabanın ortaya konmas1 gerekir.

Örgütsel sinizm, örgüte yönelik olumsuz tutumu ifade etmektedir. Çalışanların örgütlerindeki geçmiş deneyimleri ya da kişilik özellikleri gibi birçok faktörün neden olabileceği bu tutum, çalışanlarda olumsuz inanç, duygu ve davranışları harekete geçirmektedir (Abraham, 2000, s. 269). Dolayısıyla sinerjik bir örgüt yaratmak için çalışanların örgütsel sinizm tutumlarının ne düzeyde olduğunu bilmek önem taşımaktadır. Çünkü örgüte karşı olumsuz tutuma sahip olan çalışanlar etkileşim, iş birliği, kararları uygulamaya katılım gibi örgütsel sinerjinin ön koşullarına katılımda daha gönülsüz olabilirler. Eğitim örgütü çalışanları olan öğretmenlerin, örgütsel sinizm tutumlarının örgütsel sinerji algılarını ne düzeyde açıladığını araştırmanın, sinerjik bir eğitim örgütü yaratmak için uygulayıcılara ve örgütsel davranışların sonuçları hakkında alanyazına sağlayacağı katkılar dolayısıyla da araştırmacılara fayda sağlayacağı düşünülmektedir.

Örgütsel sinerji hem bireysel hem de örgütsel çabayı gerektirir. Çünkü örgütsel sinerjinin alt boyutları olan etkileşim ve takdir etme, strateji, güncellenme ve güçlenme ile bütünleşme bireysel istek olmaksızın örgütsel çabanın yetersiz kalacağı konulardır. Bununla birlikte bir grup, yalnızca üyelerin bireysel olarak üretebileceklerinin toplamı kadar üretkense, grubun kendine zarar veren veya statik bir ilisskisi vardır. Grubun bu işlevsizliği maalesef zayıf iletişim, verimsiz yönetim, güven eksikliği, savunuculuk, benmerkezcilik, bağlllık eksikliği ve rekabet gibi dinamiklerden kaynaklanmaktadır (Lick, 1999, s. 37). Örgütsel sinerji, örgütün değişim ve gelişimi için örgüt kaynaklarını etkili kullanmayı gerektirir. Bununla birlikte gelişim ve değişim için harcanan bu çaba her zaman sinerjik bir ortamın kolayca ortaya çıkmasını sağlamayabilir. Deneyimlenen başarısız girişimler çalışanların örgütsel sinizm tutumuna sahip olmalarını sağlayabilir (Wanous, Reichers ve Austin,1994, s. 264). Dolayısıyla çalışanların örgütsel sinizm tutumları ile örgütsel sinerji algıları arasında ters yönlü bir ilişkinin olduğu ve çalışanların örgütsel sinizm tutumlarının örgütsel sinerji algılarında negatif yönde bir etkiye neden olacağı düşünülmektedir. Çünkü örgütsel sinizm algısı çalışanın, çalıştığ kurumdan duyuşsal ve davranışsal uzaklaşma yaşadığı, okula karşı olumsuz tutumlara sahip olduğu, çalıstığı kurumda performansını düşüren unsurların olduğunu ve kararların alınmasına katılım sağlanmasına olanak verilmediğini düşündüğü bir inanç sistemi geliştirdiğinin 
göstergesidir. Böyle bir tutumun bireysel çabaların, bireysel ve örgütsel amaçlar doğrultusunda birleștirilerek, ortaya konulacak katkının büyük oranda artıracağını ön gören örgütsel sinerijiyi olumsuz etkileyeceği düşünülmektedir. Bu bağlamda araştırmanın amacı öğretmenlerin örgütsel sinizm tutumunun örgütsel sinerji algılarını ne düzeyde yordadığını araştırmaktır. Bu ana amaç çerçevesinde araştırmanın alt amaçları aşağıdaki gibidir:

1. Öğretmenlerin örgütsel sinizm ve örgütsel sinerji ölçeği alt boyutlarına ilişkin algılarının ne düzeyde olduğunu araştırmak.

2. Öğretmenlerin örgütsel sinizm ve örgütsel sinerji algılarının demografik özelliklerine göre farklılaşıp farklılaşmadığını araştırmak.

3. Öğretmenlerin örgütsel sinizm tutumunun örgütsel sinerji algısını ne düzeyde yordadığını araştırmak.

\section{Yöntem}

Araştırma genel tarama modellerinden ilişkisel tarama modelinde tasarlanmıştır. İlişkisel tarama modeli geçmiş ya da mevcut durumu betimlemeyi amaçlarken, iki ya da daha fazla değişken arasındaki ilişkinin varlığı ya da derecesini belirlemeye çalışan bir genel tarama modelidir (Karasar, 2003, s. 81).

\section{Evren - Örneklem}

Çalışma evreni İstanbul İli Avcılar İlçesinde görev yapan 3845 öğretmenden oluşmaktadır. Çalışmanın örneklemi ise tahmini örneklem büyüklüğü saptama tablosu $(\alpha=.05)$ kullanılarak (Çokluk, Şekercioğlu, Büyüköztürk, 2012) 357 olarak belirlenmiş ve basit tesadüfi örnekleme ile belirlenmiştir. Olası geri dönmeyen ölçek formları ya da hatalı/eksik doldurmalar göz önünde bulundurularak 500 ölçek formu dağıtılmıştır. Geri dönen 396 ölçek formuna sahip öğretmen örnekleme dahil edilmiştir. Örneklemi oluşturan öğretmenlerin demografik özelliklerine ilişkin bilgiler Tablo 1'de gösterilmiştir.

Tablo 1. Örnekleme Iliskin Demografik. Bilgiler

\begin{tabular}{llccc}
\hline \multicolumn{1}{c}{ Demografik $\boldsymbol{O}$ zellik } & & Düzey & $\overline{\boldsymbol{X}}$ & $\boldsymbol{\%}$ \\
\hline \multirow{2}{*}{ Cinsiyet } & Kadın & 289 & 73 \\
& Erkek & 107 & 27 \\
\hline \multirow{2}{*}{ Yaş } & $20-30$ & 128 & 32 \\
& $31-40$ & 177 & 45 \\
\multirow{2}{*}{ Branş } & 41 ve üzeri & 91 & 28 \\
\hline \multirow{4}{*}{ Kıdem } & Sinıf & 105 & 27 \\
& Branş & 291 & 73 \\
& $1-5$ yll & 113 & 29 \\
& 6-10 yll & 101 & 18 \\
& $11-15$ yll & 72 & 13 \\
& $16-20$ yll & 50 & 15 \\
\hline
\end{tabular}

Tablo 1 incelendiğinde araştırma örneklemini oluşturan öğretmenlerden 289'unun (\%73) kadın, 107'sinin erkek (\%27); 128'inin (\%32) 20-30 yaş aralığında, 177'sinin (\%45) 31-40 yaş aralığında, 91'inin (\%28) 41yaş ve üzerinde olduğu; 105’inin (\%27) sinif öğretmeni, 291'inin(\%73) branş öğretmeni olduğu ve 113'ünün (\%29) 1-5 yll arası kıdeme, 101'inin (\%26) 6-10 yıl arası kıdeme, 72'sinin (\%18) 11-15 yıl aras1 kıdeme, 50'sinin (\%13) 16-20 yıl arası kıdeme, 60'ının (\%15) 21 ve üzeri kıdeme sahip olduğu görülmektedir.

\section{Veri Toplama Araçları}

Örgütsel Sinižm Ölçĕgi. Sağır ve Oğuz (2012) tarafindan geliştirilen Örgütsel Sinizm ölçeği 25 madde ve 4 boyuttan oluşan geçerli ve güvenilir bir ölçektir. Ölçeğin boyutları çalıştığı kurumdan (duyuşsal, davranışsal) uzaklaşma, performansı düşüren etkenler, okula karşı olumsuz tutum ve çalışanların kararları uygulamalara katılımı şeklinde isimlendirilmiştir. Ölçeğin tamamı için güvenilirlik katsayısı $\alpha=.89^{\prime}$ 'dur. Her bir alt boyuta ilişkin güvenilirlik katsayısı sırasıyla $\alpha=.86, \alpha=.88, \alpha=.85$ ve $\alpha=.68$ 'dir.

Örgütsel Sinerji Ölçeğgi. Akpolat ve Levent (2018) tarafindan geliştirilmiş olan Örgütsel Sinerji Ölçeği, 29 madde ve 4 boyuttan oluşan geçerli ve güvenilir bir ölçektir. Ölçeğin boyutları etkileşim ve takdir etme, 
bütünleşme, strateji ve güncellenme ve güçlenme şeklinde isimlendirilmiştir. Ölçeğin toplamına ilişskin güvenilirlik katsayısı $\alpha=.97$ ve her bir alt boyuta ilişkin güvenilirlik katsayı değerleri sırasıyla $\alpha=.95, \alpha=.95$, $\alpha=.91$ ve $\alpha=.85^{\prime}$ tir.

\section{Verilerin Analizi}

Öncelikle veri seti JAMOVI ortamına aktarılmıştır. Veri setinin normallik varsayımını sağlayıp sağlamadığı basıklık-çarpıklık değeri incelenerek belirlenmiştir. Tabachnick ve Fidell (2013, s. 79), basıklık çarpıklık değerinin \pm 1.5 aralığında olmasının veri setinin normallik varsayımını karşılaması için yeterli olduğunu belirtmektedirler. Bu bağlamda her bir ölçekten elde edilen verilerin, ölçeklerin alt boyutları için basıklık çarpıklık değerlerine bakılmıştır. Örgütsel Sinerji ölçeği alt boyutlarına ilişkin basıklık çarpıklık değerleri etkileşim ve takdir etme boyutu için basıklık $=-.283$, çarpıklık $=-.402$; bütünleşme boyutu için basıklık $=.184$, çarplklık $=.437$; strateji boyutu için basıklık $=.179$, çarp1klık $=-.667$; güncellenme ve güçlenme boyutu için basıklı==-.088, çarpıklık=-.479'dur. Örgütsel Sinizm ölçeği alt boyutlarına ilişkin basıklık ve çarpıklık değerleri çalıştı̆ı kurumdan uzaklaşma boyutu için basıklık=-.665, çarpıklık=.211; performansı düşüren etkenler boyutu için basıkl1k=-.836, çarpıklık $=-.224$; okula karşı olumsuz tutum boyutu için basıklık $=.648$, çarpıklık $=.963$; kararları uygulamalara katılım boyutu için basıklık $=.245$, çarpıklık=.123'tür. Bulunan değerlerin ilgili aralıkta olduğu gözlemlenmiştir. Dolayısıyla veri setinin normallik varsayımını sağladığı sonucuna ulaşılmış ve analiz için parametrik testler kullanılmıştır.

Veri setinin analizine başlamadan önce veri toplama araçları olan Örgütsel Sinizm Ölçeği ve Örgütsel Sinerji Ölçeğine ilişkin güvenilirlik analizi yapılmıştır. Ölçeklerin toplam ve alt boyutlarına ilişkin Cronbach alfa güvenilirlik katsayıları şöyledir: Örgütsel sinizm ölçek toplamı için $\alpha=.81$, çalşstığı kurumdan (duyuşsal, davranışsal) uzaklaşma boyutu için $\alpha=.70$, performansı düşüren etkenler boyutu için $\alpha=.77$, okula karşı olumsuz tutum boyutu için $\alpha=.73$, çalışanların kararları uygulamalara katılımı boyutu için $\alpha=$ .83; örgütsel sinerji ölçek toplamı için $\alpha=.92$, etkileşim ve takdir etme boyutu için $\alpha=.89$, bütünleşme boyutu için $\alpha=.87$,strateji boyutu için $\alpha=.90$, güncellenme ve güçlenme boyutu için $\alpha=.90$ 'dır. Güvenilirlik için Cronbach alfa katsayısının .70'ten büyük olması gerektiği genel olarak kabul görmüştür. Bu bağlamda çalışmada kullanılan ölçme araçlarının güvenilir olduğu söylenebilir.

Öğretmenlerin örgütsel sinizm tutumu ve örgütsel sinerji algisının demografik değişkenlere göre farkllık gösterip göstermediği bağımsız gruplar T testi ve ANOVA ile test edilmiştir. Örgütsel sinizm ile örgütsel sinerji arasındaki ilişki Pearson korelasyon analizi test edilmiştir. Örgütsel sinizmin örgütsel sinerjiyi etkileme düzeyi ise çoklu doğrusal regresyon analizi ile test edilmiştir.

\section{Bulgular}

Öğretmenlerin örgütsel sinizm ve örgütsel sinerji algılarına ilişkin bulgular Tablo 2'de gösterilmektedir.

Tablo 2. Öğretmenlerin Örgütsel Sinižm ve Örgütsel Sinerji Algzlarna İliskin Ortalama ve Standart Sapma Değerleri

\begin{tabular}{llcc}
\hline Ölçek & Alt Boyut & $\overline{\boldsymbol{X}}$ & $\boldsymbol{s s}$ \\
\hline \multirow{3}{*}{ Örgütsel Sinizm } & Çalış̧ı̆ı̆ Kurumdan (Duyuşsal, Davranışsal) Uzaklaşma & 2.62 & 0.94 \\
& Performansı Düşüren Etkenler & 2.03 & 1.08 \\
& Okula Karşı Olumsuz Tutum & 1.84 & 0.76 \\
& Çalış̧anların Kararları Uygulamalara Katılımı & 3.00 & 0.81 \\
\hline \multirow{3}{*}{ Örgütsel Sinerji } & Etkileşim ve Takdir Etme & 3.55 & 0.87 \\
& Bütünleşme & 3.47 & 0.85 \\
& Strateji & 3.81 & 0.86 \\
& Güncelleme ve Güçlenme & 3.58 & 0.92 \\
\hline
\end{tabular}

Tablo 2 incelendiğinde öğretmenlerin örgütsel sinizmin alt boyutlarından çalıştı̆̆1 kurumdan uzaklaşma boyutuna "kararsızım" düzeyinde $(\bar{X}=2.62)$; performansı düşüren etkenler boyutuna "katılmıyorum" düzeyinde $(\bar{X}=2.03)$; okula karşı olumsuz tutum boyutuna "katılmıyorum" düzeyinde $(\bar{X}=$ 1.84) ve kararlara katılım boyutuna ise "karasızım" düzeyinde $(\bar{X}=3.00)$ katıldıkları görülmektedir. Öğretmenlerin örgütsel sinerjinin alt boyutlarından etkileşim ve takdir etme boyutuna "katıllyorum" düzeyinde ( $\bar{X}=3.55)$; bütünleşme boyutuna "kattliyorum" düzeyinde $(\bar{X}=3.47)$; strateji boyutuna "kat1liyorum" düzeyinde ( $\bar{X}=3.81)$ ve güncellenme ve güçlenme boyutuna "kat1liyorum" düzeyinde $(\bar{X}=$ 3.58) katıldıkları görülmektedir. 
Öğretmenlerin örgütsel sinizm algılarının cinsiyet ve branşlarına göre farklılaşıp farklılaşmadığını incelemek için bağımsız gruplar t testi yapılmış ve ilgili bulgular Tablo 3’te gösterilmiştir.

Tablo 3. Cinsiyet ve Branș Deģ̆̈skenlerine göre Örgütsel Sinizm Alt Boyutlarna İliskin t Testi Sonuclar

\begin{tabular}{|c|c|c|c|c|c|c|c|c|}
\hline Alt Boyutlar & Değişken & Düzey & $n$ & $\overline{\boldsymbol{X}}$ & ss & $t$ & $s d$ & $p$ \\
\hline \multirow{4}{*}{$\begin{array}{l}\text { Çalıştığ1 Kurumdan } \\
\text { Uzaklaşma }\end{array}$} & \multirow{2}{*}{ Cinsiyet } & Kadın & 289 & 2.64 & .92 & .719 & 394 & .47 \\
\hline & & Erkek & 107 & 2.57 & 1.03 & & & \\
\hline & \multirow{2}{*}{ Branş } & Sinif & 105 & 2,42 & .89 & -2.53 & 394 & .01 \\
\hline & & Branș & 291 & 2.70 & .97 & & & \\
\hline \multirow{4}{*}{$\begin{array}{l}\text { Performansı Düşüren } \\
\text { Etkenler }\end{array}$} & \multirow{2}{*}{ Cinsiyet } & Kadin & 289 & 3.02 & 1.07 & .634 & 394 & .52 \\
\hline & & Erkek & 107 & 2.94 & 1.11 & & & \\
\hline & \multirow{2}{*}{ Branş } & Sinif & 105 & 2.79 & 1.07 & -2.19 & 394 & .02 \\
\hline & & Branș & 291 & 3.07 & 1.08 & & & \\
\hline \multirow{4}{*}{$\begin{array}{l}\text { Okula Karşı Olumsuz } \\
\text { Tutum }\end{array}$} & \multirow{2}{*}{ Cinsiyet } & Kadın & 289 & 1.84 & .74 & .089 & 394 & .92 \\
\hline & & Erkek & 107 & 1.83 & .82 & & & \\
\hline & \multirow{2}{*}{ Branş } & Sinif & 105 & 1.67 & 1.60 & -2.73 & 394 & .00 \\
\hline & & Branş & 291 & 1.90 & 1.80 & & & \\
\hline \multirow{4}{*}{$\begin{array}{l}\text { Çalışanların Kararları } \\
\text { Uygulamalara Katılımı }\end{array}$} & \multirow{2}{*}{ Cinsiyet } & Kadin & 289 & 2.02 & .77 & -.599 & 394 & .54 \\
\hline & & Erkek & 107 & 2.07 & .91 & & & \\
\hline & \multirow{2}{*}{ Branş } & Sinif & 105 & 1.79 & .73 & -3.57 & 394 & .00 \\
\hline & & Branş & 291 & 2.13 & .83 & & & \\
\hline
\end{tabular}

Tablo 3 incelendiğinde örgütsel sinizmin alt boyutlarında öğretmenler cinsiyetlerine göre anlamlı fark bulunmazken, branşlarına göre her alt boyutta branşlarına göre branş öğretmenleri lehine anlamlı fark bulunduğu görülmüştür $(\mathrm{p}<.05)$.

Öğretmenlerin kıdem değişkenine göre örgütsel sinizm alt boyutlarına ilişkin algılarında anlamlı bir farklılık olup olmadığını incelemek için tek yönlü ANOVA testi yapılmıştır. Kıdem değişkenine göre öğretmenlerin örgütsel sinizm alt boyutlarında anlamlı farklılık olup olmadığının incelendiği ANOVA testine ilişkin bulgular Tablo 4'te gösterilmiştir.

Tablo 4. Kıdem Değğşkenine Göre Öğretmenlerin Örgütsel Siniz̨m Alt Boyutlarna İlişkin Tek Yönlü ANOVA Sonuclar

\begin{tabular}{|c|c|c|c|c|c|c|c|}
\hline Bağımsız Değişken & Bağımlı Dĕ̆ģsken & Kıdem & $\bar{N}$ & $\bar{X}$ & ss & $F$ & $p$ \\
\hline \multirow{20}{*}{ Kıdem } & \multirow{5}{*}{$\begin{array}{l}\text { Çalıştı̆̆1 Kurumdan } \\
\text { Uzaklaşma }\end{array}$} & $1-5 \mathrm{yll}$ & 113 & 2.60 & .93 & 4.79 & .00 \\
\hline & & $6-10 \mathrm{yll}$ & 101 & 2.68 & .97 & & \\
\hline & & $11-15$ yll & 72 & 2.80 & 1.0 & & \\
\hline & & $16-20 \mathrm{yll}$ & 50 & 2.48 & .91 & & \\
\hline & & 21 y1l ve üzeri & 60 & 2.28 & .83 & & \\
\hline & \multirow{5}{*}{$\begin{array}{l}\text { Performansı Düşüren } \\
\text { Etkenler }\end{array}$} & $1-5 \mathrm{yll}$ & 113 & 3.11 & 1.09 & 1.09 & .37 \\
\hline & & $6-10 \mathrm{yll}$ & 101 & 2.88 & 1.13 & & \\
\hline & & $11-15$ yll & 72 & 3.15 & 1.07 & & \\
\hline & & $16-20 \mathrm{yll}$ & 50 & 2.96 & 1.00 & & \\
\hline & & 21 yil ve üzeri & 60 & 2.84 & 1.03 & & \\
\hline & \multirow{5}{*}{$\begin{array}{l}\text { Okula Karşı Olumsuz } \\
\text { Tutum }\end{array}$} & $1-5 \mathrm{yll}$ & 113 & 1.86 & .78 & .974 & .43 \\
\hline & & $6-10 \mathrm{yll}$ & 101 & 1.82 & .77 & & \\
\hline & & $11-15 \mathrm{yll}$ & 72 & 1.97 & .76 & & \\
\hline & & $16-20 \mathrm{yll}$ & 50 & 1.81 & .85 & & \\
\hline & & 21 yll ve üzeri & 60 & 1.71 & .56 & & \\
\hline & \multirow{5}{*}{$\begin{array}{l}\text { Çalışanların Kararları } \\
\text { Uygulamalara Katılımı }\end{array}$} & $1-5 \mathrm{yll}$ & 113 & 1.98 & .72 & 1.11 & .32 \\
\hline & & $6-10 \mathrm{yll}$ & 101 & 2.05 & .86 & & \\
\hline & & $11-15 \mathrm{y} 1 \mathrm{l}$ & 72 & 2.23 & .98 & & \\
\hline & & $16-20 \mathrm{yll}$ & 50 & 2.00 & .76 & & \\
\hline & & 21 yil ve üzeri & 60 & 1.89 & .69 & & \\
\hline
\end{tabular}

Tablo 4 incelendiğinde öğretmenlerin kıdemlerine göre örgütsel sinizmin çalıştığı kurumdan uzaklaşma boyutunda anlamlı bir farklılık olduğu görülmektedir. Bu farkın hangi gruplar arasında olduğunu belirlemek için Post-Hoc testlerinden Tukey testi yapılmıştır. Yapılan testin sonucunda 6-10 yıl kıdeme sahip öğretmenler ve 11-15 yl kıdeme sahip öğretmenler arasında ikinci grup lehine anlamlı farkın olduğu görülmektedir ( $\mathrm{p}<.05)$. 
Öğretmenlerin yaş değişkenine göre örgütsel sinizmin alt boyutlarına ilişkin algılarında anlamlı bir farklılık olup olmadığını incelemek için tek yönlü ANOVA testi yapılmıştır. Yaş değişkenine göre öğretmenlerin örgütsel sinizm alt boyutlarında anlamlı farklılık olup olmadı̆̆ının incelendiği ANOVA testine ilişkin bulgular Tablo 5'te gösterilmiştir.

Tablo 5. Yaş Değişkenine Göre Ögretmenlerin Örgütsel Siniżm Alt Boyutlarna İlişkin Tek Yönlü ANOV A sonuçlar

\begin{tabular}{|c|c|c|c|c|c|c|c|}
\hline Bağımsız Değişken & Bağımlı Değişken & Yas & $N$ & $\bar{X}$ & ss & $F$ & $p$ \\
\hline \multirow{12}{*}{ Yaş } & \multirow{3}{*}{$\begin{array}{l}\text { Çalıştığı Kurumdan } \\
\text { Uzaklaşma }\end{array}$} & $20-30$ & 128 & 2.70 & .96 & 4.86 & .00 \\
\hline & & $31-40$ & 177 & 2.60 & .98 & & \\
\hline & & 41 ve üzeri & 91 & 2.42 & .88 & & \\
\hline & \multirow{3}{*}{$\begin{array}{l}\text { Performansı Düşüren } \\
\text { Etkenler }\end{array}$} & $20-30$ & 128 & 3.17 & 1.10 & 2.19 & .09 \\
\hline & & $31-40$ & 177 & 2.92 & 1.09 & & \\
\hline & & 41 ve üzeri & 91 & 2.92 & 1.01 & & \\
\hline & \multirow{3}{*}{$\begin{array}{l}\text { Okula Karşı Olumsuz } \\
\text { Tutum }\end{array}$} & $20-30$ & 128 & 1.89 & .76 & 1.159 & .33 \\
\hline & & $31-40$ & 177 & 1.85 & .90 & & \\
\hline & & 41 ve üzeri & 91 & 1.75 & .69 & & \\
\hline & \multirow{3}{*}{$\begin{array}{l}\text { Çalışanların Kararları } \\
\text { Uygulamalara Katılımı }\end{array}$} & $20-30$ & 128 & 2.08 & .76 & .627 & .60 \\
\hline & & $31-40$ & 177 & 2.04 & .90 & & \\
\hline & & 41 ve üzeri & 91 & 1.96 & .69 & & \\
\hline
\end{tabular}

Tablo 5 incelendiğinde öğretmenlerin yaşlarına göre örgütsel sinizmin çalıştığı kurumdan uzaklaşma boyutunda anlamlı farklıkları olduğu görülmektedir. Bu farkın hangi gruplar arasında olduğunu belirlemek için Post-Hoc testlerinde Tukey testi yapılmıştır. Yapılan testin sonucuna göre 20-30 yaş arası öğretmenler ile 41 ve üzeri yaş öğretmenler arasında birinci grup lehine anlamlı farkın olduğu görülmektedir $(\mathrm{p}<.05)$.

Öğretmenlerin örgütsel sinerji algılarının cinsiyet ve branşlanına göre farklılaşıp farklılaşmadığını incelemek için bağımsız gruplar t testi yapılmış Ve ilgili bulgular Tablo 6'da gösterilmiştir.

Tablo 6. Cinsiyet ve Brans Değiskenlerine göre Örgütsel Sinerji Alt Boyutlarna İliskin T Testi Sonucları

\begin{tabular}{|c|c|c|c|c|c|c|c|c|}
\hline Alt Boyutlar & Değişken & Düzey & $n$ & $\bar{X}$ & ss & $t$ & $s d$ & $p$ \\
\hline \multirow{4}{*}{ Etkileşim ve Takdir Etme } & \multirow{2}{*}{ Cinsiyet } & Kadın & 289 & 3.50 & .87 & -1.88 & 394 & .06 \\
\hline & & Erkek & 107 & 3.80 & .89 & & & \\
\hline & \multirow{2}{*}{ Branş } & Sinif & 105 & 3.76 & .75 & 2.79 & 394 & .00 \\
\hline & & Branş & 291 & 3.46 & .90 & & & \\
\hline \multirow{4}{*}{ Bütünleşme } & \multirow{2}{*}{ Cinsiyet } & Kadin & 289 & 3.43 & .87 & -1.65 & 394 & .10 \\
\hline & & Erkek & 107 & 3.59 & .77 & & & \\
\hline & \multirow{2}{*}{ Branş } & Sinif & 105 & 3.74 & .78 & 3.44 & 394 & .00 \\
\hline & & Branş & 291 & 3.37 & .85 & & & \\
\hline \multirow{4}{*}{ Strateji } & \multirow{2}{*}{ Cinsiyet } & Kadin & 289 & 3.80 & .87 & -.34 & 394 & .72 \\
\hline & & Erkek & 107 & 3.84 & .82 & & & \\
\hline & \multirow{2}{*}{ Branş } & Sinif & 105 & 4.01 & .80 & 2.45 & 394 & .01 \\
\hline & & Branș & 291 & 3.73 & .88 & & & \\
\hline \multirow{4}{*}{ Güncellenme ve Güçlenme } & \multirow{2}{*}{ Cinsiyet } & Kadın & 289 & 3.58 & .95 & -.04 & 394 & .96 \\
\hline & & Erkek & 107 & 3.59 & .83 & & & \\
\hline & \multirow{2}{*}{ Branş } & Sinif & 105 & 3.69 & .82 & 1.26 & 394 & .20 \\
\hline & & Branș & 291 & 3.55 & .94 & & & \\
\hline
\end{tabular}

Tablo 6 incelendiğinde öğretmenlerin cinsiyetlerine göre örgütsel sinerjinin alt boyutlarında anlamlı farkın olmadığı görülmektedir. Öğretmenlerin branşlarına göre örgütsel sinerjinin etkileşim ve takdir etme, bütünleşme ve strateji alt boyutlarında sınıf öğretmenleri lehine anlamlı farkın olduğu görülmektedir $(\mathrm{p}<.05)$.

Öğretmenlerin kıdem değişkenine göre örgütsel sinerji alt boyutlarına ilişkin alg1larında anlamlı bir farklılık olup olmadığını incelemek için tek yönlü ANOVA testi yapılmıştır. Kıdem değişkenine göre öğretmenlerin örgütsel sinerji alt boyutlarında anlamlı farklılık olup olmadığının incelendiği ANOVA testine ilişkin bulgular Tablo 7 de gösterilmiştir. 
Tablo 7. Kıdem Değğskenine Göre Ögrretmenlerin Örgütsel Sinerji Alt Boyutlarna İliskin Tek Yönlü ANOVA Sonuclar

\begin{tabular}{|c|c|c|c|c|c|c|c|}
\hline Bağımsız Değişken & Bağımlı Değişken & Kidem & $N$ & $\bar{X}$ & ss & $F$ & $p$ \\
\hline \multirow{20}{*}{ K1dem } & \multirow{5}{*}{$\begin{array}{l}\text { Etkileşim ve Takdir } \\
\text { Etme }\end{array}$} & $1-5 \mathrm{yll}$ & 113 & 3.48 & .97 & 2.82 & .01 \\
\hline & & $6-10 \mathrm{y} 1 \mathrm{l}$ & 101 & 3.57 & .88 & \multirow{9}{*}{1.17} & \multirow{9}{*}{.32} \\
\hline & & $11-15$ yll & 72 & 3.34 & .95 & & \\
\hline & & $16-20 \mathrm{y} 1 \mathrm{l}$ & 50 & 3.68 & .69 & & \\
\hline & & 21-y1l ve üzeri & 60 & 3.80 & .72 & & \\
\hline & \multirow{5}{*}{ Bütünleşme } & $1-5 \mathrm{yll}$ & 113 & 3.43 & .95 & & \\
\hline & & $6-10$ yil & 101 & 3.54 & .86 & & \\
\hline & & $11-15 \mathrm{yll}$ & 72 & 3.31 & .87 & & \\
\hline & & $16-20 \mathrm{y} 1 \mathrm{l}$ & 50 & 3.49 & .73 & & \\
\hline & & 21-yıl ve üzeri & 60 & 3.62 & .86 & & \\
\hline & \multirow{5}{*}{ Strateji } & $1-5 \mathrm{yll}$ & 113 & 3.87 & .95 & \multirow[t]{5}{*}{1.68} & \multirow[t]{5}{*}{.14} \\
\hline & & $6-10 \mathrm{yll}$ & 101 & 3.89 & .81 & & \\
\hline & & $11-15 \mathrm{yll}$ & 72 & 3.60 & .89 & & \\
\hline & & $16-20 \mathrm{yll}$ & 50 & 3.89 & .73 & & \\
\hline & & 21-yıl ve üzeri & 60 & 3.91 & .96 & & \\
\hline & \multirow{5}{*}{$\begin{array}{l}\text { Güncellenme ve } \\
\text { Güçlenme }\end{array}$} & $1-5 \mathrm{yll}$ & 113 & 3.49 & 1.10 & \multirow[t]{5}{*}{2.64} & \multirow[t]{5}{*}{.04} \\
\hline & & $6-10 \mathrm{yll}$ & 101 & 3.69 & .80 & & \\
\hline & & $11-15$ yil & 72 & 3.40 & .96 & & \\
\hline & & $16-20 \mathrm{y} 1 \mathrm{l}$ & 50 & 3.57 & .75 & & \\
\hline & & 21-yıl ve üzeri & 60 & 3.81 & .81 & & \\
\hline
\end{tabular}

Tablo 7 incelendiğinde öğretmenlerin kıdemlerine göre örgütsel sinerjinin etkileşim ve takdir etme boyutu ile güncellenme ve boyutlarında anlamlı farklılı olduğu görülmektedir. Bu anlamlı farkın hangi gruplar arasında olduğunu belirleyebilmek için Post-Hoc testlerinden Tukey testi yapılmıştır. Bu testin sonuçlarına göre etkileşim ve takdir etme boyutunda 11-15 yll kıdeme sahip öğretmenler ile 21 yl ve üzeri kıdeme sahip öğretmenler arasında ikinci grup lehine anlamlı fark bulunmaktadır ( $\mathrm{p}<.05)$. Güncellenme ve güçlenme boyutunda ise 11-15 yll kıdeme sahip öğretmenler ile 21 yll ve üzeri kıdeme sahip öğretmenler arasında ikinci grup lehine ( $\mathrm{p}<.05)$ anlamlı fark olduğu görülmüştür.

Öğretmenlerin yaş değişkenine göre örgütsel sinerji alt boyutlarına ilişkin algılarında anlamlı bir farklılık olup olmadığını incelemek için tek yönlü ANOVA testi yapılmıştır. Yaş değişkenine göre öğretmenlerin anlamlı iş alt boyutlarında anlamlı farklılık olup olmadığının incelendiği ANOVA testine ilişkin bulgular Tablo 8 de gösterilmiştir

Tablo 8. Yaş Değiskeenine Göre Öğretmenlerin Örgütsel Sinerji Alt Boyutlarna İliskin Tek Yönlü ANOV A Sonuclar

\begin{tabular}{|c|c|c|c|c|c|c|c|}
\hline Bağımsız Değişken & Bağımlı Değıişken & Yaş & $N$ & $\overline{\bar{X}}$ & $s s$ & $F$ & $p$ \\
\hline \multirow{12}{*}{ Yaş } & \multirow{3}{*}{$\begin{array}{l}\text { Etkileşim ve Takdir } \\
\text { Etme }\end{array}$} & $20-30$ & 128 & 3.43 & .96 & 4.29 & .00 \\
\hline & & $31-40$ & 177 & 3.53 & .89 & & \\
\hline & & 41 ve üzeri & 91 & 3.76 & .67 & & \\
\hline & \multirow{3}{*}{ Bütünleşme } & $20-30$ & 128 & 3.37 & .95 & 2.09 & .10 \\
\hline & & $31-40$ & 177 & 3.51 & .80 & & \\
\hline & & 41 ve üzeri & 91 & 3.55 & .77 & & \\
\hline & \multirow{3}{*}{ Strateji } & $20-30$ & 128 & 3.84 & .90 & .63 & .59 \\
\hline & & $31-40$ & 177 & 3.80 & .86 & & \\
\hline & & 41 ve üzeri & 91 & 3.88 & .86 & & \\
\hline & \multirow{3}{*}{$\begin{array}{l}\text { Güncellenme ve } \\
\text { Güçlenme }\end{array}$} & $20-30$ & 128 & 3.42 & 1.05 & 3.231 & .04 \\
\hline & & $31-40$ & 177 & 3.62 & .87 & & \\
\hline & & 41 ve üzeri & 91 & 3.74 & .79 & & \\
\hline
\end{tabular}

Tablo 8 incelendiğinde öğretmenlerin yaşlarına göre örgütsel sinerjinin etkileşim ve takdir etme boyutu ile güncellenme ve güçlenme boyutlarında anlamlı farklılıkların olduğu görülmektedir. Bu farkın hangi gruplar arasında olduğunu belirlemek için Post-Hoc testlerinden Tukey Testi yapilmıştır. Bu testin sonucunda etkileşim ve takdir etme boyutunda 20-30 yaş grubu öğretmenler ile 41 ve üzeri yaş grubu öğretmenler arasında ikinci grup lehine $(\mathrm{p}<.05)$ anlamlı farkın olduğu görülmüştür. Güncellenme ve 
güçlenme boyutunda da 20-30 yaş grubu öğretmenler ile 41 ve üzeri yaş grubu öğretmenler arasında ikinci grup lehine anlamlı farkın olduğu görülmüsstür $(\mathrm{p}<.05)$.

Öğretmenlerin örgütsel sinizm tutumu ile örgütsel sinerji alg1sı arasındaki ilişkiyi incelemek üzere Pearson korelasyon katsayıları hesaplanmıştır. Analize ilişkin bulgular Tablo 9'da gösterilmektedir.

Tablo 9. Örgütsel Sinizm ve Örgütsel Sinerji Puanlarna İliskin Pearson Korelasyon Katsaynlar

\begin{tabular}{lcccc}
\hline Boyutlar & $\begin{array}{c}\text { Etkileşim ve } \\
\text { Takdir Etme }\end{array}$ & Bütünleşme & Strateji & $\begin{array}{c}\text { Güncellenme } \\
\text { ve Güçlenme }\end{array}$ \\
\hline Çalış̧ı̆ğ Kurumdan Uzaklaşma & $-.639^{* *}$ & $-.646^{* *}$ & $-.610^{* *}$ & $-.554^{* *}$ \\
Performansı Düşüren Etkenler & $-.535^{* *}$ & $-.570^{* *}$ & $-.506^{* *}$ & $-.445^{* *}$ \\
Okula Karş1 Olumsuz Tutum & $-.568^{* *}$ & $-.571^{* *}$ & $-.535^{* *}$ & $-.487^{* *}$ \\
Çalışanların Kararları Uygulamalara Katılımı & $-.468^{* *}$ & $-.533^{* *}$ & $-.479^{* *}$ & $-.405^{* *}$ \\
\hline
\end{tabular}
$* * \mathrm{p}<.001$

Tablo 9 incelendiğinde örgütsel sinizmin çalıştı̆̆ kurumdan uzaklaşma boyutu ile örgütsel sinerjinin etkileşim ve takdir etme, bütünleşme ve strateji boyutları arasında ter yönde yüksek düzeyde bir ilişkinin, güncellenme ve güçlenme boyutuyla ters yönlü orta düzeyde bir ilişkinin olduğu görülmektedir. Performansı düşüren etkenler, okula karşı olumsuz tutum ve çalışanların kararları uygulamalara katılımı boyutları ile örgütsel sinerjinin tüm boyutları arasında ters yönlü orta düzeyde bir ilişkinin olduğu görülmektedir.

Öğretmenlerin örgütsel sinizm tutumunun alg1ladıkları örgütsel sinerji düzeyine etkisini incelemek için çoklu regresyon analizi yapılmıştır. Analize ilişkin bulgular Tablo10'da sunulmuştur.

Tablo 10. Örgütsel Sinizm Alt Boyutlarnm Örgütsel Sinerizyi Etkileme Düreyine Illişkin Coklu Regresyon Sonuclarn

\begin{tabular}{|c|c|c|c|c|c|c|}
\hline Örgütsel Sinizm Boyutları & $B$ & $\begin{array}{c}\text { Standart } \\
\text { Hata }\end{array}$ & Beta & $t$ & $p$ & $\overline{V I F}$ \\
\hline (Sabit) & 5.521 & .09 & & 61.27 & .000 & \\
\hline Çalıştığı kurumdan uzaklaşma & -.317 & .04 & -.378 & -7.24 & .000 & 2.50 \\
\hline Performansı düşüren etmenler & -.128 & .033 & -.179 & -3.97 & .000 & 1.87 \\
\hline Okula karşı olumsuz tutum & -.122 & .05 & -.116 & -2.34 & .020 & 2.23 \\
\hline Kararları uygulamalar katılım & -.243 & .03 & -.259 & -6.79 & .000 & 1.33 \\
\hline $\mathrm{R}^{2}=.573$ & \multirow{2}{*}{\multicolumn{2}{|c|}{$\begin{array}{l}\text { Düzeltilmiş } \mathrm{R}^{2}=.569 \\
\mathrm{p}<.001\end{array}$}} & \multirow{2}{*}{\multicolumn{3}{|c|}{ Durbin-Watson $(\mathrm{d})=1.94$}} & \\
\hline $\mathrm{F}=131$ & & & & & & \\
\hline
\end{tabular}

Tablo 10 incelendiğinde VIF değerinin 10'un altında olduğu (Albayrak, 2008, s. 131) ve DurbinWatson değerinin ilgili aralıkta (1,5-2,5) (Kalayc1, 2009, s. 267) olduğu görülmektedir. Bu durum bağımsız değişkenler arasında çoklu doğrusallık sorununun olmadığının göstergesidir. Örgütsel sinizmin her bir alt boyutunun örgütsel sinerjiyi ters yönde anlamlı bir şekilde etkilediği görülmektedir. Öğretmenlerin örgütsel sinizm tutumlarının örgütsel sinerji algılarını açıklama düzeyinin \%57 olduğu görülmektedir.

\section{Tartışma, Sonuç ve Öneriler}

Öğretmenlerin örgütsel sinizm ölçeği alt boyutlarına verdikleri cevapların ortalamalarına bakıldığında kararlara katılım ve çalşstı̆̆ kurumdan uzaklaşma boyutlarında "kararsızım" düzeyinde diğer boyutlarda "katılmıyorum" düzeyinde örgütsel sinizm tutumuna sahip oldukları söylenebilir. Dolayısıyla çalışmaya katılan öğretmenler düşük düzeyde örgütsel sinizm tutumuna sahiptir. Bu bulgu alanyazındaki çalışmaların sonuçlarıyla tutarlılık göstermektedir (Kılıç, 2011, s. 63; Yıldız, 2013, s. 864). Öğretmenler en yüksek düzeyde kararlara katıllım boyutunda örgütsel sinizm tutumuna sahiptirler. Bu sonuç alanyazındaki örgütsel sinizm çalışmalarının sonuçlarıyla tutarlılık göstermektedir (Altınkurt, Yılmaz, Erol ve Salalı, 2014, s. 33; Okçu, Şahin ve Şahin, 2015, s. 305). Kararlara katılım boyutu öğretmenlerin okullarında alınması gereken kararlara katılmak isteme düzeyini, yöneticilerinin öğretmenleri karar alma süreçlerine dahil etmesi ile ilgili öğretmen algılarını ifade eden boyutudur. Öğretmenlerin kararlara katılım boyutunda en yüksek düzeyde örgütsel sinizm yaşıyor olmaları, karar süreçlerine dahil olmak istememeleri ya da dahil edilmedikleri şeklindeki algılarının yüksek olması demektir. Bununla birlikte öğretmenler en düşük düzeyde okula karşı olumsuz tutum boyutunda örgütsel sinizm yaşamaktadırlar. Okula karş1 olumsuz tutum boyutu, öğretmenlerin okullarına karşı hissettikleri çaresizlik, önemsememe, sinirlenme, öfkelenme ve utanma gibi duyguları ifade etmektedir. Öğretmenlerin örgütsel sinizmi en düşük düzeyde bu boyutta yaşamaları okullarına karşı bu tür duygulara sahip olmadıklarının göstergesidir. Bu bulgu Altınkurt vd.'nin (2014, s. 
33) bulgularıly benzerlik gösterirken, Okçu vd. (2015, s. 305) öğretmenlerin performans1 düşüren etkenler şeklinde yaşadıkları örgütsel sinizm tutumunun en düşük düzeyde olduğunu belirtmişlerdir.

Öğretmenlerin örgütsel sinerji ölçeği alt boyutlarına verdikleri cevapların ortalamalarına bakıldığında her boyutu "katıllyorum" düzeyinde algıladıkları görülmektedir. Dolayısıyla öğretmenlerin örgütsel sinerji alg1 düzeyinin yüksek olduğu söylenebilir. Öğretmenler örgütsel sinerijiyi en yüksek düzeyde strateji boyutunda algılarken, en düşük düzeyde bütünleşme boyutunda algılamaktadırlar. Akpolat ve Levent (2020, s. 951) yaptıkları çalşsmanın sonucunda öğretmenlerin en yüksek düzeyde strateji ve en düşük düzeyde bütünleşme biçimde örgütsel sinerji algıladıklarını belirtmişlerdir. Strateji boyutu örgütte yapılacak işlerin kim tarafından ne zaman, nasıl yapılacağını ve sürdürüleceğini ifade eden örgütsel sinerji boyutudur. Örgütsel sinerji yaratma sürecinde dişsal motivasyonu sağlayan boyut olarak da düşünülebilir. Çünkü bir sürece başlamak ve kontrol etmek için gerekli olan unsurların nasıl algılandığı ile ilgilidir. Bütünleşme ise stratejinin tersine yaratıcılık, esneklik, inisiyatif alma ve geçmiş deneyimlerden potansiyel çözümler üretmeyi içeren örgütsel sinerjinin belirsiz ortamları firsata çevirmeyi içeren boyutudur (Akpolat ve Levent, 2018, s. 741). Milli Eğitim Sisteminin merkezi ve hiyerarşik yapıs1, merkezi yönetimden gelen kararların örgüt içinde doğrudan uygulanmasına neden olmaktadır. Bu durum öğretmenlerin örgütsel sinerjinin yasal tarafinı oluşturan strateji boyutunda yüksek düzeyde örgütsel sinerji algılamalarını açklayabilir. Aynı durum örgütsel sinerjinin çeşitlilik yönetimi, yaratıclık ve inovasyon tarafını oluşturan bütünleşme boyutunda ögretmenlerin algılarının düşük olmasını açıklamaktadır.

Öğretmenlerin cinsiyetlerine göre örgütsel sinizm tutumları farklılaşmamaktadır. Öğretmenlerin örgütlerine olan tutumlarının cinsiyetten bağımsız olarak oluştuğu söylenebilir. Nitekim alanyazında örgütsel sinizm tutumunun cinsiyete göre farklılaşmadığ1 sonucuna ulaşan çalışmalar mevcuttur (Akpolat ve Oğuz, 2015, s. 951; Ergen ve İnce, 2017, s. 46; Gökyer ve Türkoğlu, 2018, s. 324; Nartgün ve Kartal, 2013, s. 56). Bununla birlikte örgütsel sinizmin tüm alt boyutlarında branş öğretmenlerinin sınıf öğretmenlerine göre daha yüksek düzeyde örgütsel sinizm yaşamaktadırlar. Yaş ve kıdem değişkenlerinin örgütsel sinizm tutumunda bir farklılaşmaya neden olduğu ve en küçük grubun en büyük gruba göre daha yüksek düzeyde örgütsel sinizm yaşadıkları sonucuna ulaşılmıştır. Mesleğe yeni başlayan öğretmenler bulundukları örgütü ve kültürünü anlama süreci içinde olduklarından, yaş ve kıdem bakımından en yüksek tecrübeye sahip öğretmenden farklı bir tutum içerisinde olabilirler.

Öğretmenlerin cinsiyetlerine göre örgütsel sinerji algisı değişmemektedir. Bu bulgu Akpolat ve Levent'in (2020, s. 954) çalışma bulgusuyla desteklenmektedir. Bununla birlikte sınıf öğretmenlerinin branş öğretmenlerine göre etkileşim ve takdir etme, bütünleşme ve strateji şeklindeki örgütsel sinerji algiları daha yüksektir. 51 ve üzeri yaşa sahip öğretmenler 20-30 yaş arası öğretmenlere göre ve 26 yıl üzeri kıdeme sahip öğretmenler 11-15 yıl kıdeme sahip öğretmenlere göre etkileşim ve takdir etme ile güncellenme güçlenme boyutlarında daha yüksek düzeyde örgütsel sinerji algilamaktadırlar. Akpolat ve Levent (2020, s. 959) kıdem ve yaş arttıkça etkileşim ve takdir etme şeklinde algılanan örgütsel sinerjinin arttığını belirtmektedirler. Etkileşim ve takdir etme boyutu etkili dinleme, iletişime açık olma, duygusal olarak güvende hissetme, samimi olarak duygu ve düşüncelerini paylaşma gibi unsurları içermektedir. Yaş ve kıdem arttıkça artan mesleki tecrübe ile öğretmenlerin inanç ve değerlerini yansıtma ve diğer öğretmenlere yardımc1 olma düzeylerinin arttığı söylenmektedir (Leithwood, 1990, s. 28). Bu durum etkileşim ve takdir etme ile güncellenme ve güçlenme boyutlarında yüksek kıdem ve yaşa sahip öğretmenlerin daha yüksek örgütsel sinerji algılamalarını açıklamaktadır. 11-15 yıl kıdeme sahip öğretmenlerse Bakioğlu'nun (1996, s. 5) deneycilik/aktivizm evresi adı ile belirttiği kariyer evresindedirler. Bu evre öğretmenleri en yüksek düzeyde bireyselleştiği, hırslı ve gayretli oldukları, örgütsel engellerden dolayı gerilimi daha yüksek düzeyde yaşadıkları evredir. Dolayısıyla bu evredeki öğretmenlerin etkileşim ve takdir etme ve güncellenme ve güçlenme boyutlarında beklentileri, yüksek kıdem ve yaşa sahip öğretmenlerden daha farklı olabilir. $\mathrm{Bu}$ durum da bu boyutlarda daha düşük düzeyde örgütsel sinerji algilamalarına neden olabilir.

Örgütsel sinizmin alt boyutları ile örgütsel sinerjinin alt boyutları arasında ters yönlü bir ilişki vardır. Bununla birlikte örgütsel sinizmin tüm alt boyutları örgütsel sinerjiyi ters yönde yordamaktadır. Bu bulgu örgütsel sinizmin olumlu örgütsel davranışlar üzerindeki olumsuz etkisini bir kez daha doğrulamaktadır. Çalışanların örgütten uzaklaşması, performanslarını düşüren unsurların varlığına dair inançları, okula karşı olumsuz duygular hissetmeleri ve kararlara katılmamaları örgütte yaratılacak sinerjinin önündeki engeller olarak karşımıza çıkmaktadır. Alanyazında örgütsel sinizmin örgütsel sinerji üzerine etkisinden bahseden herhangi bir çalışma bulunmamaktadır. Dolayısıyla bu sonucu örgütsel sinizmin benzer örgütsel davranışlar üzerindeki etkisini tartsşarak bir sonuca bağlamak yerinde olacaktır. Örgütsel sinizm tutumu 
çalışanların örgütsel değişimlerde gönüllü olarak çalışmasını engellemektedir (Wanous, Reichers ve Austin, 1994, s. 273). Örgütsel sinerji ise hem örgütsel hem de bireysel çabanın sonucunda ortaya çıkacaktır. Bu durum örgütsel sinizmin örgütsel sinerjiyi olumsuz etkilemesini açıklamaktadır. Örgütsel sinerjinin etkileşim ve takdir etme boyutu örgüt içindeki iletişim ortamının nasıl algilandığı ile ilgilidir. Yazıcıoğlu (2019, s. 79) örgütsel sinizmin etkin iletişim ortamını negatif yönde etkilediğini belirtmektedir. Örgütsel sinerjinin bütünleşme boyutu, inisiyatif alma, esneklik, yaratıcılık gibi bürokratik sistemin kabuğunun kırılması ile mümkün olabilecek süreçleri ifade etmektedir. Karaoğlan (2019, s. 68) öğretmenlerin okulun bürokratik yapısına ilişkin algılarının örgütsel sinizmi artırdığını ifade etmektedir. Dolayısıyla bu durum örgütsel sinizmin bütünleşme boyutunda algilanan örgütsel sinerjinin azalmasına neden olmasını açıklamaktadır. Örgütsel sinerjinin güncellenme ve güçlenme boyutu mesleki gelişim için öğretmenlerin çabalarını ve bu çabaların sonuçlarını örgüt için kullanmalarını ifade etmektedir. Mahmood ve Sak (2019, s. 2253) örgütsel sinizm arttıkça kişisel başarının azalacağını ifade etmektedir. Bununla birlikte Duman, Sak ve Sak (2020, s. 1122) meslekleri ile ilgili herhangi bir etkinliğe katılmış öğretmenlerin böyle bir etkinliğe katılmamış olan öğretmenlere göre örgütsel sinizm düzeyinin daha düşük olduğunu belirtmektedir. Bu durum da örgütsel sinizmin, ögretmenlerin güncellenme ve güçlenme boyutunda algiladığı örgütsel sinerjiyi olumsuz etkilemesini açıklamaktadır.

Tüm sonuçlar okullarda sinerji yaratabilmek için dikkat edilmesi gereken birkaç unsura dikkat çekmektedir. Demografik değişkenlere göre branş öğretmenleri, kıdemi ve yaş1 daha küçük olan öğretmenler için örgütsel sinizm tutumlarını azaltacak önlemler alınması gerekmektedir. Bunun için kıdemli öğretmenlerden mesleğe yeni başlamış olan öğretmenlere mentorluk yapmalarının istenmesi önerilmektedir. Karar alma ve uygulama süreçlerine öğretmenleri dahil edilmesi önemlidir. Bu noktada karar alma ve uygulama süreçleri yapılması gereken işler için takımlar oluşturulması şeklinde anlaşılmamalıdır. İşlerin "neden” yapılması gerektiği ile ilgili güçlü argümanların hem öğretmenler hem de yöneticiler tarafindan ortaya konulması ve bu doğrultuda ortak kararlar alınması hem öğretmenler hem de örgüt için anlamlı sonuçlar yaratacaktır. 11-15 yll kıdeme sahip öğretmenlerin en kıdemli öğretmenlere göre daha düşük örgütsel sinerji algılamaları, potansiyellerini açığa çıkaramamaları şeklinde okunabilir. Bu durumu Aristoteles'in (2015) Nikamokhas'a Etik kitabında bahsettiği aktüel ve potansiyel kavramları üzerinden açıklamak yerinde olacaktır. Maddenin şimdiki hali (aktüel) ve açığa çıkarılabilecek başka halleri (potansiyel) vardır. Bu durumu çalışma bulgusunu oluşturan 11-15 yıl kıdeme sahip öğretmenler özelinde irdelemek gerekirse, mesleki uzmanlıklarının zirvesinde olan bu öğretmenler (Bakioğlu, 1996, s. 5) mevcut durum (aktüel) ile yetinemeyip, potansiyellerini açığa çıkarmak istiyor olabilirler. Dolayısıyla bu kariyer evresindeki öğretmenler ile problemler hakkında yaratıcı süreçlerin işlediği bir iletişim, örgütsel sinerji yaratmak adına önem taşımaktadır.

\section{Etik Beyan}

“"Öroütsel Siniżm Alglanan Örgütsel Sinerizyi Nasıl Etkiler? Ë̈itim Örgütlerinde Bir İnceleme” başlıklı çalışmanın yazım sürecinde bilimsel kurallara, etik ve alıntı kurallarına uyulmuş; toplanan veriler üzerinde herhangi bir tahrifat yapilmamış ve bu çalışma herhangi başka bir akademik yayın ortamına değerlendirme için gönderilmemiştir. Gerekli olan etik kurul izinleri Mimar Sinan Güzel Sanatlar Üniversitesi Sosyal ve Beşeri Bilimler Araştırma ve Yayın Etiği Kurulu'nun 02.11.2020 tarih ve 18565 sayılı yazısı ile alınmıştır. Çalışmaya katılım gönüllülük esasına dayanmaktadır. Katılımcılara çalışmanın amacını, toplanacak verilerin bilimsel çalışma kapsamında kullanılacağını, herhangi bir kişisel bilginin talep edilmediğini ve çalısmanın herhangi anında vazgeçme haklarının olduğu belirtilmiş ayrıca tüm bu bilgiler yazılı olarak etik onam formu ile katılımcılara verilmiştir.

\section{Kaynakça}

Abraham, R. (2000). Organizational cynicism: Bases and consequences. Genetic, Social, and General Psychology Monographs, 126(3), 269-292.

Al Shaar, E. M., Khattab, S. A., Alkaied, R. N. ve Manna, A. Q. (2015). The effect of top management support on innovation: The mediating role of synergy between organizational structure and information technology. International Review of Management and Business Research, 4(2), 499-511.

Akın, U. (2015). Okullarda örgütsel sinizm ve güven ilişkisinin incelenmesi: Öğretmenler üzerinde bir araştırma. Ë̆itim ve Bilim, 40(181), 175-189.

Akpolat, T. ve Oğuz, E. (2015). İlkokul ve ortaokul öğretmenlerinde örgütsel sinizmin işe yabancılaşma düzeyine etkisi. Mersin University Journal of the Faculty of Education, 11(3), 947-971.

Akpolat, T. ve Levent, A. F. (2018). Öğretmenlere yönelik örgütsel sinerji ölçeği’nin geliştirilmesi. Mersin Üniversitesi Eğitim Fakiultesi Dergisi, 14(2), 728-744. 
Akpolat, T. ve Levent, A. F. (2020). Öğretmenlerin algılarına göre okullardaki örgütsel sinerji düzeyinin incelenmesi. EJER Congress 2020 Tam Metin Kitabı, Eskişehir.

Altınkurt, Y., Yılmaz, K., Erol, E. ve Salalı, E. T. (2014). Okul müdürlerinin kullandığı güç kaynakları ile öğretmenlerin örgütsel sinizm algılar1 arasındaki ilişki. Journal of Teacher Education and Educators, 3(1), 25-52.

Amabile, T. M. (1997). Entrepreneurial creativity through motivational synergy. The Journal of Creative Behavior, 31(1), 18-26.

Andersson, L. M. (1996). Employee cynicism: An examination using a contract violation framework. Human Relations, 49(11), 1395-1418.

Andersson, L. M. ve Bateman, T. S. (1997). Cynicism in the workplace: Some causes and effects. Journal of Organizational Behavior: The International Journal of Industrial, Occupational and Organizational Psychology and Behavior, 18(5), 449-469.

Aristoteles (2015). Nikamaktos'a etik (Çev: F. Akderin). İstanbul: Say Yayınları.

Bakioğlu, A. (1996). Öğretmenlerin kariyer evreleri. Atatürk Eğitim Fakültesi 2. Ulusal Eğitim Sempozyumu Bildirileri, 1820 Eylül, İstanbul.

Bölükbaşığlu, K. (2013). Öğretmenlerin örgütsel adalet algzlar ile örgütsel siniżm tutumlar arasindaki ilişki (Yüksek lisans tezi). Pamukkale Üniversitesi, Denizli.

Conner, D. R. (1993). Managing at the speed of change. New York: Villard.

Covey, S. R. (2002). Etkili İnsanların Yedi Alışkanlı̆̆ı. İstanbul: Varlık Yayınlar.

Dean, J. W., Brandes, P. ve Dharwadkar, R. (1998). Organizational cynicism. Academy of Management Review, 23(2), 341-352.

Duman, N., Sak, R. ve Sak, İ. T. Ş. (2020). Öğretmenlerin mesleki tükenmişlik düzeyleri ile örgütsel sinizm tutumlarının incelenmesi. Yüzüncü Yal Üniversitesi Eğitim Fakültesi Dergisi, 17(1), 1098-1127.

Ergen, H. ve İnce, Ş. (2017). İlköğretim kurumlarında çalışan öğretmenlerin örgütsel sinizm düzeyleri: Mersin örneği. Hacettepe Eğitim Araștırmalar Dergisi, 3(1).37-57.

Ersoy, E. ve Levent, F. (2020). Öğretmen algılarına göre örgütsel güç mesafesi ile örgütsel sinerji düzeyi arasındaki ilişkinin incelenmesi. İstanbul Aydin Üniversitesi Dergisi, 12(4), 345-356.

Goold, M. ve Campbell, A. (1998). Desperately seeking synergy. Harvard Business Review, 76(5), 131-143.

Gökyer, N. ve Türkoğlu, İ. (2018). Liselerde görev yapan öğretmenlerin örgütsel destek alg1ları ile örgütsel sinizm tutumları arasındaki ilişki. Ë̆itim ve Bilim, 43(196), 317-340.

Güngör, D. (2019). Insan kaynaklar departman çalşanlarmm örgütsel sinizm algılarmm işten ayrlma niyeti üzerine etkisi (Yüksek Lisans Tezi). Sakarya Üniversitesi, Sakarya.

Harris, P. R. (2004). European leadership in cultural synergy. European Business Review, 16(4), 358-380.

Helvacı, M. A. ve Çetin, A. (2012). İlköğretim okullarında görev yapan öğretmenlerin örgütsel sinizm düzeylerinin belirlenmesi (Uşak ili örneği). Turkish Studies (Elektronik), 7(3 b), 1475-1497.

Jadesadalug, V. ve Ussahawanitchakit, P. (2008). The impacts of organizational synergy and autonomy on new product performance: moderating effects of corporate mindset and innovation. Journal of International Business Strategy, 8(3), 118-128.

James, M. S. L. (2005). Antecedents and consequences of cynicism in organizations: An examination of the potential positive and negative effects on school systems (Doctoral Dissertation). The Florida State University, Florida, USA. Retrieved form https:// fsu.digital.flvc.org/islandora/object/fsu:181909/datastream/PDF/view

Johnson, J. L. ve O'Leary-Kelly, A. M. (2003). The effects of psychological contract breach and organizational cynicism: Not all social exchange violations are created equal. Journal of Organizational Behavior: The International Journal of Industrial, Occupational and Organizational Psychology and Behavior, 24(5), 627-647.

Kahya, C. (2013). Örgütsel sinizm, iş performansını etkiler mi? İş tatminin aracılık etkisi. Global Journal of Economics and Business Studies, 2(3), 34-46.

Karasar, N. (2003). Bilimsel araștrrma yöntemi. Ankara: Nobel.

Karaoğlan, Ö. (2019). Okullarn bürokratik yapısı, örgütsel sessiz̨lik ve örgütsel siniz̨m arasındaki ilişki (Yüksek Lisans Tezi). Pamukkale Üniversitesi, Denizli.

Keskinkılıç-Kara, S. B. ve Oğuz, E. (2016). Relationship between political discrimination level perceived by teachers and teachers' organizational cynicism levels. Eurasian Journal of Educational Research, 16(63), 55-70.

K1lıç, Ş. (2011). Illkögretim okulu ögretmenlerinin örgütsel siniz̨m ve örgütsel bağhllı düzeyleri arasindaki ilişki: Keçiören ilçesi örneği (Yüksek Lisans Tezi). Hacettepe Üniversitesi, Ankara.

Li, E. Y., Chen, J. S. ve Huang, Y. H. (2006). A framework for investigating the impact of IT capability and organisational capability on firm performance in the late industrializing context. International Journal of Technology Management, 36(1-3), 209-229.

Lick, D. W. (1999). Proactive comentoring relationships: Enhancing effectiveness through synergy. In Carol A. Mullen \& Dale W. Lick (Eds), New directions in mentoring, creating a culture of synergy (pp. 34-45). London: Falmer Presss.

Leithwood, K. A. (1990). The principals role in teacher development. In Michael Fullan \& Andy Hargreaves (Eds), Teacher development and educational change (pp. 86-101), New York: Routledge.

Mahmood, S. M. R. ve Sak, R. (2019). Okul öncesi öğretmenlerinin mesleki tükenmişlik düzeyleri ile örgütsel sinizm tutumları arasındaki ilişkinin incelenmesi. Kastamonu Ë̆itim Dergisi, 27(5), 2243-2259. 
Mert, G. ve Yılmaz, G. (2019). Beş yıldızlı otellerde örgütsel sinizmin işletme performansına etkisinde motivasyon rolünün incelenmesi. Turkish Studies, 14 (2), 629-650.

Nartgün, S. S. ve Kartal, V. (2013). Öğretmenlerin örgütsel sinizm ve örgütsel sessizlik hakkındaki görüşleri. Bartın Üniversitesi Ë̆itim Fakültesi Dergisi, 2(2), 47-67.

Okçu, V., Şahin, H. M. ve Şahin, E. (2015). Beden eğitimi ve spor öğretmenlerinin örgütsel sinizme ilișkin algıllarının örgütsel bağl1lıkları üzerindeki etkisi. International Journal of Sport Culture and Science, 3(Special Issue 4), 298-313.

Sağır, T. ve Oğuz, E. (2012). Öğretmenlere yönelik örgütsel sinizm ölçeğinin geliştirilmesi. International Journal of Human Sciences, 9(2), 1094-1106.

Senge, P. (2002). Beşinci disiplin (Çev: A. İldeniz ve A. Doğukan). İstanbul: Yap1 Kredi Yayınları.

Simbula, S. ve Guglielmi, D. (2010). Depersonalization or cynicism, efficacy or inefficacy: What are the dimensions of teacher burnout?. European Pournal of psychology of Education, 25(3), 301-314.

Tabachnick, B. ve Fidell, L. (2013). Using multivariate statistics (6th International edition). London, UK: Pearson.

Töremen, F. (2001). Okul yönetiminde bir tür yaratıc1lık: sinerji. Furat Üniversitesi Sosyal Bilimler Dergisi, 11(1), 201-212.

Wanous, J. P., Reichers, A. E. ve Austin, J. T. (1994). Organizational cynicism: An initial study. Academy of Management Best Papers Proceedings, 1, 269-273.

Wilkerson, J. M. (2002). Organizational cynicism and its impact on human resources management. Human Resources Management: Perspectives, Context, Functions, and Outcomes, 532-546.

Yazıcıoğlu, N. (2019). Kurum içi etkin iletişim ortam ile örgütsel siniz̨m arasındaki ilişki (Yüksek Lisans Tezi). İstanbul Sabahattin Zaim Üniversitesi, İstanbul.

Yıldız, K. (2013). Örgütsel bağll1ık ile örgütsel sinizm ve örgütsel muhalefet arasındaki ilişki. Turkish Studies, 8(6), 853879.

\section{EXTENDED ABSTRACT}

Employees' experiences in their organizations cover a wide range of positive and negative beliefs and behaviors. Employee attitudes are of great importance for the efficiency and effectiveness of organizations. In this context, it is important to know to what extent the negative attitudes of the employees cause which perceptions.

Organizational cynicism generally expresses a negative attitude towards the organization (procedures, processes, management) in which a person is employed. Moreover, this negative attitude is generally based on a belief that these elements (procedure, process, management) in the organization work against the benefit of the employee (Wilkerson, 2002, p. 553). Dean, Brandes, and Dharwadkar (1998, p.345) define organizational cynicism in purely attitudinal terms, focusing on beliefs that reflect attitude, affect, and behavioral intentions. Beliefs from these three dimensions of organizational cynicism include employees' beliefs that organizational practices lack justice, honesty and sincerity, that personal interests are at the forefront, that people are unreliable, and that hidden agendas work under their behavior. The Affect dimension expresses strong emotional states such as distress, disgust, and shame that employees feel about their organization. The behaviors dimension includes negative and degrading behaviors. It is said that the most prominent type of behavior of organizational cynicism is sarcasm.

Organizational synergy has entered the literature as a concept used to express the partnerships of organizations doing different jobs with the impact of globalization and digitalization on the business world to realize organizational activities such as creativity in their own work, new product development or facilitating any process within the organization. However, organizational synergy, by definition, refers to a process in which the internal elements of the organization work together for organizational success. The concept of synergy is widely discussed for groups in society, business and education as an approach used to effectively improve processes. For example, Covey (2002, p. 278) defines synergy as one of seven basic habits. Senge (2002) discusses team learning as one of the key disciplines of successful groups; Synergy is cited as a critical part of team learning. It has proven to be a powerful tool that increases efficiency in living spaces where synergy is successfully produced (Lick, 1999, p. 34). Synergy is collaborative or combined action. It occurs when different individuals or groups of people collaborate for a common purpose. The aim is to increase efficiency by sharing perceptions and experiences, insights and information (Harris, 2004, p. 364).

The research was designed in relational scanning model, one of the general scanning models. While the relational screening model aims to describe the past or current situation, it is a general survey model that tries to determine the existence or degree of the relationship between two or more variables (Karasar, 2003, p. 81). The population of the study consists of 3845 teachers working in Avc1lar District of Istanbul Province. The sample of the study was determined as 357 using the estimated sample size determination table (Çokluk, Şekercioğlu, \& Büyüköztürk, 2012) and was determined by simple random sampling. 
Considering possible non-returning scale forms or incorrect / incomplete filling, 500 scale forms were distributed. Teachers with 396 scale forms returning were included in the sample. The Organizational Cynicism Scale and the Organizational Synergy Scale were used as data collection tools in the study.

Teachers participating in the study have a low level of organizational cynicism. This finding is consistent with the results of the studies in the literature (Kılıç, 2011, p. 63; Yıldız, 2013, p. 864). It can be said that the organizational synergy perception level of teachers is high. There is an inverse relationship between the sub-dimensions of organizational cynicism and the sub-dimensions of organizational synergy. However, all sub-dimensions of organizational cynicism adversely affect organizational synergy. This finding confirms once again the negative impact of organizational cynicism on positive organizational behavior. Employees' distancing from the organization, their belief in the existence of factors that reduce their performance, their negative feelings towards the school and they are not participating in the implementation of the decisions appear as obstacles to the synergy to be created in the organization. All results highlight a few factors that need to be considered in order to create synergy in schools. According to demographic variables, measures should be taken to reduce organizational cynicism attitudes for branch teachers, seniority and younger teachers. For this, senior teachers may be asked to mentor teachers who have just started the profession. It is important to involve teachers in decision-making and implementation processes. At this point, decision-making and implementation processes should not be understood as forming teams for the work to be done. Putting strong arguments about "why" the work that needs to be done here by both teachers and administrators and taking joint decisions in this direction will create meaningful results for both teachers and the organization. Teachers with 11-15 years of seniority have a lower perception of organizational synergy than the most senior teachers, and their inability to reveal their potential. Because these teachers, who are at the top of their professional expertise, may not be content with the current situation (actual) mentioned by Aristotle (2015) in his book Nicomachean Ethics, and may want to reveal their potential. Therefore, a communication with teachers in this career phase about the problems through creative processes is important in order to create organizational synergy. 